\title{
Characteristics of General Soils, Natural Saltlicks and Artificial Saltlicks for Wild Asian Elephants (Elephas Maximus) Conservation in the Western Forests of Thailand
}

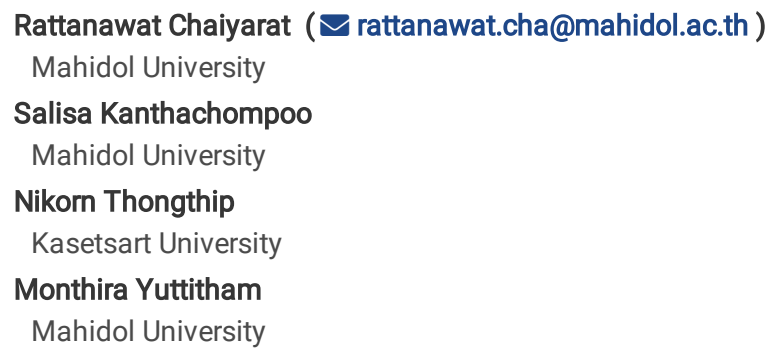




\section{Abstract}

Saltlicks are a keystone resource of wildlife. This study aimed to compare the characteristics among general soil, natural saltlicks and artificial saltlicks in the natural forest of Salakphra Wildlife Sanctuary (SWS) and restoration habitat for elephant (Elephas maximus) in Kui Buri National Park (KNP), western Thailand. Twenty general soils, 33 natural and 35 artificial saltlicks were analyzed. The chemical compositions in natural saltlicks were not consistent. The $\mathrm{K}, \mathrm{Mg}, \mathrm{Fe}$ and $\mathrm{Cu}$ in natural saltlicks were higher than artificial saltlicks in both areas. The Ca and Zn in artificial saltlicks in SES were higher than natural saltlicks of KNP. The salinity in artificial saltlicks was highest and higher than in natural saltlicks in both areas and can provide supplemental $\mathrm{Na}$, thereby increasing salinity in both areas. The artificial saltlicks cannot provide $\mathrm{Ca}, \mathrm{K}, \mathrm{Mg}$, Fe and Cu when compared to natural saltlicks that can provide a primary target for elephants at these sites. The findings have consequences for conservation of elephants and other large herbivores by supplementing essential macro- and micro-nutrients in artificial saltlicks. The key resources can provide information to help maintain the wildlife health and fecundity of the region.

\section{Introduction}

The distribution range of the Asian elephants (Elephas maximus) is western India, Sri Lanka, northern India, and Himalayan countries such as Nepal, Bangladesh, Myanmar, Thailand, China, Lao PDR, Cambodia, Vietnam, Malaysia, Sumatra Island and Borneo Island ${ }^{1}$. The total population has been estimated to be 41,410-52,345 Asian elephants worldwide ${ }^{2}$. Perera ${ }^{3}$ reported that the distribution of wild elephants has increased in Bhutan, India, Sumatra Island and Thailand. Elephants are the symbolic animal of Thailand. In Thailand, the overall population trend was considered constant between 2003 and 2009. The total wild elephant population in the protected areas of Thailand was estimated at 3,000-3,500 elephant in 56,270 km² 4 . In SWS, an estimated 180 elephants with increased activity near saltlicks were reported ${ }^{5}$. While in KNP, approximately 168 elephants were concentrated in The King's project area, which highlights the importance of habitat improvement to elephants. In the King's project area, 12 small reservoirs were created, and many ponds and hundreds of check dams were built to keep water all year round ${ }^{6}$. About 30 artificial saltlicks were also created. In addition, two ranger stations were established in 1998 and 2004 in both Kui canal valleys to provide safety for the elephants ${ }^{7}$.

Elephants need food every 12 hours with a dry weight of $1.5 \%$ of their body weight during dry season and $1.9 \%$ in the wet season ${ }^{8}$. Elephants directly receive minerals such as phosphorus $(\mathrm{P})$, calcium $(\mathrm{Ca})$, sodium $(\mathrm{Na})$, and potassium $(\mathrm{K})$ from food especially in mineral rich soils ${ }^{9}$, but some nutrients such as sodium ( $\mathrm{Na}$ ), sulfur $(\mathrm{S})$ and magnesium $(\mathrm{Mg})$ cannot be obtained from most plants ${ }^{10}$. Both Asian and African wild elephants (Loxodonta africana) must receive these minerals from others sources such as soil, drinking water ${ }^{11-14}$ or termite mounds in the case of African elephants ${ }^{15}$. The macronutrients included $\mathrm{Na}, \mathrm{Ca}, \mathrm{Mg}, \mathrm{K}, \mathrm{P}$, and $\mathrm{S}$ with an average value at 356.1, 1,540.2, 389.7, 158.4, 61.0, 62.9 and 16.0 ppm respectively. Various natural sources contain $\mathrm{Na}$. Geophagia by herbivore mammals will assist in controlling $\mathrm{Na}$ and help in controlling hungriness ${ }^{16}$. Soil consumption is more obvious when the minerals in nature are decreased ${ }^{17}$. Mostly, wildlife was found to eat the saltlicks to supplement Ca and Na intake. In areas, which lack the required soil nutrients or natural saltlicks, artificial saltlicks are suitable to manage the habitat and maintain the elephants' health ${ }^{18-21}$.

When the agricultural areas were expansion invading in forest areas; especially slash and burn agriculture at the beginning of 19th century reduced the wild elephant habitat in both African and Asian elephants ${ }^{22}$. These activities cause elephant-human conflict (HEC) for more than 100 years ${ }^{23-25}$. Causes of conflict can be summarized as land use changes such as forest land use, logging and secondary forest. This made the elephants moved closer to human habitats ${ }^{22}$. In addition, artificial water sources built adjacent to forests attracted wild elephants to come out of the forest, particularly in dry season ${ }^{26}$. Moreover, building barriers on the travel routes of the elephants affected the elephant's behavior to be more aggressive27. Wild elephant's behavior and ecological characteristics been changed such as some populations that have become familiar with people ${ }^{28}$. Socioeconomics and politics have changed; for example, expansion of pineapple crops by Dole Company from Hawaii, USA in Kui Buri District in Prachuap Khiri Khan province in $1967^{29}$. Later, there was agricultural expansion as the governmental policy aimed for the local people to settle in forest areas during that period. As a consequence, it has caused conflict between people and wild elephants.

In Thailand, critical issues from wild elephants include damaging agricultural and crop products, accidents and killing people. The trends have continually increased. It found in at least 14 preserved areas such as Phu Luang Wildlife Sanctuary, Phu Kradueng National Park, or KNP, due to expansion of the pineapple crop industry, wild elephants damaged crops by eating the pineapples both in dry and rainy season. This has been a longterm issue until projects were initiated by His Majesty the King and the guidelines set to solve the problems between people and wild elephants ${ }^{6}$. Nelson et al. ${ }^{23}$ and Perera ${ }^{3}$ suggested methods to solve conflicts between people and wild elephants which included traditional methods, killing elephants, translocation, repellant methods, physical barriers, compensation schemes, wildlife utilization schemes and land use planning. Artificial saltlicks are one of several methods to solve the problems between elephant and human conflict ${ }^{30}$. Consequently, distribution of natural saltlicks for elephants is not suitable. Even if elephants are able to take up nutrients from plants, some minerals are insufficient for wild elephants' needs, resulting in lack of minerals in their bodies. This is evident in male wild elephants that require high Ca to form teeth, tusks and bones18-21. The female wild elephants also need Ca during pregnancy or nursing a baby, because primary minerals of elephants are highly vital for breast milk. The World Wide Fund for Nature ${ }^{29}$ reported that the $S$ intake of wild elephants was not adequate, and it is necessary for wild elephants and other mammals to supplement minerals by consuming saltlicks ${ }^{31,32}$. However, there is no previous study exhibiting that minerals in saltlicks are sufficient for wild elephants. SWS and KNP located in the western forest of Thailand are well known for habitat of wild elephants. Wild elephants in these two areas are known to utilize in agricultural areas and consume agricultural products. These events chronically lead to conflict between humans and wild elephants despite both SWS and KNP being divergent as conservation areas. 
The SWS is a natural forest, while KNP is a restored forest. Although both areas have saltlicks, there has been no clear approach and standard analysis of mineral content in either artificial or naturally occurring saltlicks. We aim to determine whether or not minerals in both the artificial and natural saltlicks of SWS and KNP are sufficient for wild elephants. These finding are important in terms of providing standardized approach to ensure that the mineral requirements of elephants are met with the provision of artificial saltlicks, thereby potentially decreasing human-elephant conflict.

\section{Materials And Methods}

Sample collection. This work was conducted under an appropriate animal ethics approval (COA. No. MU-IACUC 2019/008), permission of the Department of National Parks, Wildlife and Plant Conservation, the Ministry of Natural Resources and Environment (MNRE 0907.4/4772).

Study sites. Salakphra Wildlife Sanctuary is located in Kanchanaburi province and is $858.55 \mathrm{~km} 2$ in size. It is located from latitude $14^{\circ} 9^{\prime}$ to $14^{\circ} 40^{\prime} \mathrm{N}$ and longitude $99^{\circ} 9^{\prime}$ to $99^{\circ} 30^{\prime} \mathrm{E}$. Most areas form a mountainous complex with $50-1,178 \mathrm{~m}$ height differences from mean sea level. The highest mountain peak is Kao Hua Loan Mountain, $1,178 \mathrm{~m}$ from mean sea level. Average highest temperature is $34^{\circ} \mathrm{C}$ and lowest temperature is $23.1^{\circ} \mathrm{C}$. Important water sources are Kao Huai Sadong and Huai Salakphra which are located in the central part of the area. Its length is approximately $26 \mathrm{~km}$. Plant communities include dry dipterocarp forest, dry evergreen forest, mixed deciduous forest, bamboo forest and tropical grassland. The geology is Karst topography, metamorphic rock and sedimentary rock. There is also a small amount of igneous (granite) rock in this area ${ }^{33}$ (Fig. 1). Kui Buri National Park is located in Prachuap Khiri Khan province and is $969 \mathrm{~km} 2$ in size ( $14^{\circ} 9^{\prime}$ to $14^{\circ} 41^{\prime} \mathrm{N}$ and $99^{\circ} 10^{\prime}$ to $99^{\circ} 25^{\prime} \mathrm{E}$ ). The geography is mostly part of the mountain range complex of Tenasserim ridge with an average elevation of $750 \mathrm{~m}$ above sea level. The forest community consists of mixed deciduous forest, dry evergreen forest and tropical rainforest ${ }^{34}$ (Fig. 1).

Field surveys. The locations of natural and artificial saltlicks were recorded by rangers under the SMART Patrol System in both SWS and KNP. From the distribution of natural and artificial saltlicks in the Geographic Information System maps of SWS and KNP, 50 locations of soil samples (12 general soils, 23 natural saltlicks and 15 artificial saltlicks) in SWS, and in 38 locations of soil samples (eight general soils, 10 natural saltlicks and 20 artificial saltlicks) in KNP were randomly selected (Fig. 2). Soils alongside neighboring at $10 \mathrm{~m}$ from saltlicks were collected with a shovel. At a consistent depth of $2 \mathrm{~cm}$ at least one $\mathrm{kg}$ of soil was collected in a clean container at each sample site ${ }^{35}$. Soil sample locations were recorded. All samples were sent to laboratory of the Faculty of Environment and Resource Studies, Mahidol University were standard analysis methodologies of the United States Department of Agriculture was performed ${ }^{36}$.

Soil chemical analysis. Cation exchange capacity (CEC) and saturation of exchangeable bases (Ca, Mg, $\mathrm{K}$ and $\mathrm{Na}$ ) were determined using ammonium acetate (one natural and neutral). Electrical conductivity (EC) was determined in a saturation extract, and particle size (texture) identification was performed using the hydrometer method ${ }^{37}$. Phosphorus $(P)$ was determined using the Bray II method. Trace elements (Fe, Cu, Mn, and $\mathrm{Zn}$ ) were extracted with DTPA ${ }^{38}$. Organic carbon concentration was determined by the Walkley-Black method ${ }^{39}$. The pH was also determined for each sample ${ }^{40}$. The results of these analyses were compared to the control samples $(n=7)$ that were obtained from $30 \mathrm{~cm}$ below the soil surface in places where there was no evidence of geophagy.

Statistical analysis. Box plots were used to illustrate the distribution of data among different treatments. ANOVA were performed to identify whether the soil reaction, salinity and chemical composition (macro- and micro-nutrient) of the soil types between the two study areas were different from one another with significant differences set at the $p$-value $=0.05$ level. The correlative coherence analysis (CCA) was used to test the relationships between 10 minerals and environmental parameters ( $\mathrm{pH}$ and salinity) among general soil, natural saltlicks and artificial saltlicks samples in Salakphra Wildlife Sanctuary and Kui Buri National Park (NSOSWS = general soils in Salakphra Wildlife Sanctuary, ASASWS = artificial saltlicks in Salakphra Wildlife Sanctuary, NSASWS = natural saltlicks in Salakphra Wildlife Sanctuary, NSOKNP = general soils in Kui Buri National Park, ASAKNP $=$ artificial saltlicks in Kui Buri National Park and NSAKNP = natural saltlicks in Kui Buri National Park). The CCA was done using PC-ORD 5.1 41.

\section{Results}

Soil reaction and salinity. Soil reaction $(\mathrm{pH})$ was significantly different among general soils, natural saltlicks and artificial saltlicks $\left(F=14.737, d f_{1,2}=5\right.$, $82, p<0.0001)$. In SWS samples were significantly different $(p<0.05)$, while KNP samples were not significantly different $(p>0.05)$. General soils in SWS $(6.8 \pm 0.5 \mathrm{ppm})$ were lowest, while natural saltlicks in SWS $(8.7 \pm 0.5 \mathrm{ppm})$ were highest in $\mathrm{pH}$. After salts and minerals were supplemented, the pH of artificial saltlicks in SWS was higher than KNP (Table 1 and Fig. 2). 
Table 1

Chemical composition among general soil, natural saltlicks and artificial saltlicks in Salakphra Wildlife Sanctuary and Kui Buri National Park

\begin{tabular}{|c|c|c|c|c|c|c|c|c|c|}
\hline \multirow[t]{2}{*}{ Parameter } & \multicolumn{3}{|c|}{ Salakphra Wildlife Sanctuary (ppm) } & \multicolumn{3}{|c|}{ Kui Buri National Park (ppm) } & \multirow[t]{2}{*}{$F$} & \multirow{2}{*}{$\begin{array}{l}d f 1 \\
2\end{array}$} & \multirow[t]{2}{*}{$p$-value } \\
\hline & $\begin{array}{l}\text { General } \\
\text { soil } \\
(n=12)\end{array}$ & $\begin{array}{l}\text { Artificial } \\
\text { saltlick } \\
(n=15)\end{array}$ & $\begin{array}{l}\text { Natural } \\
\text { saltlick } \\
(n=23)\end{array}$ & $\begin{array}{l}\text { General soil } \\
(n=8)\end{array}$ & $\begin{array}{l}\text { Artificial saltlick } \\
(n=20)\end{array}$ & $\begin{array}{l}\text { Natural saltlick } \\
(n=10)\end{array}$ & & & \\
\hline $\mathrm{pH}$ & $6.8 \pm 0.5 a$ & $7.7 \pm 0.6 b$ & $8.7 \pm 0.5 c$ & $7.3 \pm 1.4 \mathrm{ab}$ & $7.2 \pm 1.1 \mathrm{ab}$ & $7.3 \pm 0.8 \mathrm{ab}$ & 14.737 & $\begin{array}{l}5, \\
82\end{array}$ & $\begin{array}{l}< \\
0.000 .1\end{array}$ \\
\hline Salinity & $\begin{array}{l}372.6 \pm \\
185.7 a\end{array}$ & $\begin{array}{l}8,507.8 \pm \\
8,197.3 \mathrm{~b}\end{array}$ & $\begin{array}{l}1,967.4 \pm \\
881.1 \mathrm{a}\end{array}$ & $979.5 \pm 895.6 a$ & $\begin{array}{l}16,774.7 \pm \\
9,148.6 \mathrm{c}\end{array}$ & $9,583.8 \pm 6,551.3 b$ & 7.116 & $\begin{array}{l}5, \\
82\end{array}$ & $\begin{array}{l}< \\
0.000 .1\end{array}$ \\
\hline$P$ & $\begin{array}{l}559.8 \pm \\
196.6 \mathrm{~b}\end{array}$ & $\begin{array}{l}614.8 \pm \\
236.2 \mathrm{~b}\end{array}$ & $\begin{array}{l}676.2 \pm \\
342.8 \mathrm{~b}\end{array}$ & $324.1 \pm 91.3 a$ & $347.8 \pm 86.9 a$ & $378.2 \pm 107.2 \mathrm{a}$ & 5.875 & $\begin{array}{l}5, \\
82\end{array}$ & $\begin{array}{l}<.000 .1 \\
0.0\end{array}$ \\
\hline K & $\begin{array}{l}1,262.9 \pm \\
580.6 \mathrm{~cd}\end{array}$ & $\begin{array}{l}963.6 \pm \\
270.5 \mathrm{bc}\end{array}$ & $\begin{array}{l}1,378.6 \pm \\
423.7 d\end{array}$ & $954.0 \pm 458.9 a b$ & $566.8 \pm 498.9 a$ & $954.3 \pm 461.5 b c$ & 2.167 & $\begin{array}{l}5 \\
82\end{array}$ & 0.066 \\
\hline $\mathrm{Ca}$ & $\begin{array}{l}191.7 \pm \\
115.6 a\end{array}$ & $\begin{array}{l}850.3 \pm \\
1135.1 a\end{array}$ & $\begin{array}{l}932.2 \pm \\
977.0 \mathrm{a}\end{array}$ & $89.7 \pm 104.9 a$ & $1,054.7 \pm 1,298.5 a$ & $3,021.7 \pm 2,793.5 b$ & 15.729 & $\begin{array}{l}5, \\
82\end{array}$ & $\begin{array}{l}< \\
0.000 .1\end{array}$ \\
\hline $\mathrm{Mg}$ & $\begin{array}{l}2,046.0 \pm \\
758.1 a\end{array}$ & $\begin{array}{l}4,693.5 \pm \\
1,035.0 \mathrm{~b}\end{array}$ & $\begin{array}{l}6,643.3 \pm \\
2,315.0 \mathrm{c}\end{array}$ & $3,212.4 \pm 1,337.1 a$ & $2,879.5 \pm 1,728.0 a$ & $7,377.5 \pm 4,084.2 \mathrm{c}$ & 3.284 & $\begin{array}{l}5, \\
82\end{array}$ & 0.009 \\
\hline $\mathrm{Na}$ & $\begin{array}{l}649.1 \pm \\
390.5 a\end{array}$ & $\begin{array}{l}1,282.3 \pm \\
963.3 a b\end{array}$ & $\begin{array}{l}1,745.6 \pm \\
1,189.0 \mathrm{~b}\end{array}$ & $583.6 \pm 444.6 a$ & $1,500.5 \pm 996.4 b$ & $1,577.0 \pm 1,424.1 b$ & 3.197 & $\begin{array}{l}5 \\
82\end{array}$ & 0.011 \\
\hline $\mathrm{Mn}$ & $\begin{array}{l}749.8 \pm \\
378.8 b\end{array}$ & $\begin{array}{l}1,148.8 \pm \\
564.7 \mathrm{c}\end{array}$ & $\begin{array}{l}1,086.3 \pm \\
494.6 \mathrm{c}\end{array}$ & $271.9 \pm 144.9 a$ & $271.9 \pm 144.9 a$ & $237.9 \pm 116.8 a$ & 3.472 & $\begin{array}{l}5 \\
82\end{array}$ & 0.007 \\
\hline $\mathrm{Zn}$ & $\begin{array}{l}25.6 \pm \\
9.5 a\end{array}$ & $\begin{array}{l}47.7 \pm \\
20.5 b\end{array}$ & $\begin{array}{l}43.9 \pm \\
11.7 \mathrm{~b}\end{array}$ & $17.6 \pm 6.7 a$ & $17.8 \pm 9.0 \mathrm{a}$ & $27.1 \pm 11.1 \mathrm{a}$ & 2.140 & $\begin{array}{l}5, \\
82\end{array}$ & 0.069 \\
\hline $\mathrm{Fe}$ & $\begin{array}{l}8,006.1 \pm \\
4,511.5 \mathrm{a}\end{array}$ & $\begin{array}{l}14,138.2 \pm \\
5,357.5 b\end{array}$ & $\begin{array}{l}18,890.1 \pm \\
6,279.9 \mathrm{c}\end{array}$ & $10,462.5 \pm 2,316.3 \mathrm{ab}$ & $6,796.9 \pm 4,629.0 a$ & $14,761.6 \pm 7,899.9 b c$ & 2.444 & $\begin{array}{l}5, \\
82\end{array}$ & 0.041 \\
\hline $\mathrm{Cu}$ & $\begin{array}{l}18.0 \pm \\
9.3 \mathrm{bc}\end{array}$ & $\begin{array}{l}24.7 \pm \\
16.4 \mathrm{~cd}\end{array}$ & $\begin{array}{l}30.6 \pm \\
14.3 d\end{array}$ & $8.6 \pm 2.6 a$ & $9.4 \pm 5.0 \mathrm{ab}$ & $11.3 \pm 3.1 \mathrm{ab}$ & 3.046 & $\begin{array}{l}5, \\
82\end{array}$ & 0.014 \\
\hline $\mathrm{Se}$ & $1.7 \pm 0.2 b$ & $1.7 \pm 0.2 b$ & $1.8 \pm 0.2 b$ & $1.6 \pm 0.18 a b$ & $1.8 \pm 0.16 b$ & $1.7 \pm 0.10 \mathrm{~b}$ & 1.348 & $\begin{array}{l}5 \\
82\end{array}$ & 0.252 \\
\hline
\end{tabular}

Salinity among general soils, natural and artificial saltlicks was significantly different $(F=7.116, d f 1,2=5,82, p<0.0001)$. Natural saltlicks in SWS were lower than in KNP $(\mathrm{P}<0.05)$. Supplementation by added salts increased the salinity in artificial saltlicks in SWS and KNP (Table 1 and Fig. 2$)$.

Macronutreints. Concentrations of P was significantly different $(F=7.116, d f 1,2=5,82, p<0.0001)$ among the experiments, but inside the SWS and KNP were not significantly different $(p>0.05)$. Phosphorus was highest in natural saltlicks in SWS. In general soils and natural saltlicks in SWS were higher than general soils and natural saltlicks in KNP $(p<0.05)$. After supplement of minerals $\mathrm{P}$ in artificial saltlicks of SWS was higher than KNP $(p<0.05)$ (Table 1 and Fig. 2).

Concentrations of $\mathrm{K}$ among general soils, natural saltlicks and artificial saltlick were not significantly different $\left(F=2.167, d f_{1,2}=5,82, p=0.066\right)$. The $\mathrm{K}$ in natural saltlicks was significant different from artificial saltlicks in SWS $(p<0.05)$. Comparisons between artificial saltlicks in SWS and natural saltlicks in KNP were not significantly different $(p>0.05)$ (Table 1 and Fig. 2$)$.

Calcium among general soils, artificial saltlicks and natural saltlick soils were significantly different $\left(F=15.729, d f_{1,2}=5,82, p<0.0001\right)$. Calcium among general soils, artificial saltlicks and natural saltlick soils in SWS were not significantly different $(p>0.05)$. The Ca was significantly different only with natural saltlicks in KNP $(p<0.05)$ (Table 1 and Fig. 2).

Concentration of Mg was significantly differently among experiments ( $\left.F=3.284, d f_{1,2}=5,82, p=0.009\right)$. The Mg was not significantly different among general soils in SWS, general soils and artificial saltlicks in KNP $(p>0.05)$. The Mg was highest in natural saltlicks in KNP ( $<<0.05)($ Table 1 and Fig. 2$)$

The Na was significantly different among general soils, natural saltlicks and artificial saltlicks $\left(F=3.197, d f_{1,2}=5,82, p=0.011\right)$. Concentrations of Na were not significantly different between natural and artificial saltlicks in both areas $(p>0.05)$. These saltlicks were significantly higher than in general soils in both areas $(p<0.05)$ (Table 1 and Fig. 2).

Concentrations of $\mathrm{Mn}$ were significantly different among general soils and natural saltlicks and artificial saltlicks $\left(F=3.472, d f_{1,2}=5,82, p=0.007\right)$. In KNP, they were not significantly different among the experiments $(p>0.05)$, but the artificial saltlicks were significantly higher than general soils $(p<$ $0.05)$, but were not significantly different with natural saltlicks $(p>0.05)$ (Table 1 and Fig. 2$)$.

Page $4 / 12$ 
Micronutrients. Concentrations of Zn among general soils, natural saltlicks and artificial saltlicks were not significantly different $\left(F=2.140, d f_{1,2}=5,82\right.$, $p=0.069)$. The $\mathrm{Zn}$ in artificial saltlicks and natural saltlicks in SWS were significant different among other general soils and natural and artificial saltlicks $(p<0.05)$ (Table 1 and Fig. 2).

Concentrations of Fe in SWS were significantly different among general soils, natural and artificial saltlicks $\left(F=2.444, d f_{1,2}=5,82, p=0.041\right)$. In SWS, Fe among general soils, artificial saltlicks and natural saltlicks were significant different $(p<0.05)$, while in KNP, Fe in artificial saltlicks were lower than general soils and artificial saltlicks $(p<0.05)$ (Table 1 and Fig. 2$)$.

Concentrations of Cu significantly different among general soils, artificial saltlicks and natural saltlicks $\left(F=3.046, d f_{1,2}=5,82, p=0.014\right)$. The Cu in artificial saltlicks and natural saltlicks were significantly different from general soils in both areas $(p<0.05)$, but artificial saltlicks in KNP when compare to other saltlicks in both areas $(\mathrm{P}<0.05)$ (Table 1 and Fig. 2).

Concentrations of Se among general soils, artificial saltlicks and natural saltlicks were not significantly different $\left(F=1.348, d f_{1,2}=5,82, p=0.252\right)$ (Table 1 and Fig. 2)

Relationships among artificial, natural saltlicks and general soils. The relationships among artificial, natural saltlicks and general soils in SWS and KNP, environmental factors and minerals was analyzed by using CCA (Table 2 and Fig. 3). The natural saltlicks in SWS (NSASWS) had a high pH and contained high levels of $\mathrm{P}, \mathrm{K}, \mathrm{Zn}, \mathrm{Fe}, \mathrm{Cu}$ and Mn, while naturals saltlick in KNP (NSAKNP) and artificial saltlick in both area (ASASWS and ASAKNP) had a high level of salinity and contained high levels of $\mathrm{Ca}, \mathrm{Na}, \mathrm{Mg}$ and $\mathrm{Se}$.

Table 2

Factor loading eigenvalue, saltlicks, minerals and coordinates of sites of correlative coherence analysis (CCA) in Salakphra Wildlife Sanctuary and Kui Buri National Park

\begin{tabular}{|llllll|}
\hline Protected area & Factor & Abbreviation & PC1 & PC2 & PC3 \\
\hline eigenvalue & & & 0.027 & 0.003 & 0.023 \\
Salakpra Wildlife Sanctuary & General soils & NSOSWS & 1.674 & 2.822 & -1.999 \\
& Artificial saltlicks & ASASWS & 0.468 & -1.089 & -0.687 \\
\cline { 2 - 6 } Kui Buri National Park & Natural saltlicks & NSASWS & 0.464 & -1.127 & -0.448 \\
& General soils & NSOKNP & 1.313 & -0.502 & -0.714 \\
& Artificial saltlicks & ASAKNP & -1.436 & 0.804 & 0.666 \\
\cline { 2 - 6 } & Natural saltlicks & NSAKNP & -1.761 & 0.718 & 2.112 \\
\hline pH & pH & -0.150 & -1.047 & 0.000 \\
\hline Salinity & Salinity & -1.039 & -0.201 & 0.000 \\
\hline Phosphorus & P & 0.109 & 0.110 & -0.27 \\
\hline Potassium & K & 0.239 & 0.191 & -0.149 \\
\hline Calcium & Ca & -0.554 & 0.089 & 0.460 \\
\hline Magnesium & Mg & -0.075 & -0.028 & 0.121 \\
\hline Sodium & Na & -0.269 & -0.019 & -0.092 \\
\hline Manganese & Mn & 0.198 & -0.056 & -0.443 \\
\hline Zing & Zn & 0.036 & -0.005 & -0.233 \\
\hline Ferrous & Fe & 0.067 & -0.013 & -0.027 \\
\hline Copper & Cu & 0.149 & -0.063 & -0.293 \\
\hline & Selenium & Se & -0.024 & 0.229 & -0.189 \\
\hline
\end{tabular}

\section{Discussion}

Macronutrients (P, K, Ca and Mg) and micronutrients ( $\mathrm{Zn}, \mathrm{Mn}, \mathrm{Fe}$ and $\mathrm{Cu}$ ) in natural saltlicks in SWS was higher than in KNP, but they were higher than those in the natural saltlicks in Huai Kha Khaeng Wildlife Sanctuary ${ }^{42}$, Phu Khieo Wildlife Sanctuary ${ }^{43}$ and natural saltlicks utilized by elephants in Mt. Elgon National Park ${ }^{44}$ (Table 3). 
Table 3

Mineral composition of general soils, artificial saltlicks, natural saltlicks and Asian elephants (Elephas maximus)' forages and bloods

\begin{tabular}{|c|c|c|c|c|c|c|c|c|c|c|c|c|c|}
\hline \multirow[t]{2}{*}{ Locality } & \multirow[t]{2}{*}{$\mathrm{pH}$} & Salanity & \multicolumn{5}{|c|}{ Macronutrient (ppm) } & \multicolumn{5}{|c|}{ Micronutrient (ppm) } & \multirow{2}{*}{$\begin{array}{l}\text { Reference: } \\
\text { Modified } \\
\text { from }\end{array}$} \\
\hline & & (ppm) & $\mathbf{P}$ & K & $\mathrm{Ca}$ & $\mathrm{Mg}$ & $\mathrm{Na}$ & $\mathrm{Mn}$ & $\mathrm{Zn}$ & $\mathrm{Fe}$ & $\mathrm{Cu}$ & $\mathrm{Se}$ & \\
\hline \multicolumn{14}{|l|}{ SWS } \\
\hline General soil & 6.8 & 372.6 & 559.8 & $1,262.9$ & 191.7 & 2,046 & 649.1 & 749.8 & 25.6 & $8,006.1$ & 18.0 & 1.7 & This study \\
\hline $\begin{array}{l}\text { Artificial } \\
\text { saltlicks }\end{array}$ & 7.7 & $8,507.8$ & 614.8 & 963.6 & 850.3 & $4,693.5$ & $1,282.3$ & 1148.8 & 47.7 & $14,138.2$ & 24.7 & 1.7 & This study \\
\hline $\begin{array}{l}\text { Natural } \\
\text { saltlicks }\end{array}$ & 8.7 & $1,967.4$ & 676.2 & $1,378.6$ & 932.2 & $6,643.3$ & $1,745.6$ & 1086.3 & 43.9 & $18,890.1$ & 30.6 & 1.8 & This study \\
\hline \multicolumn{14}{|l|}{ KNP } \\
\hline General soil & 7.3 & 979.5 & 324.1 & 954.0 & 89.7 & $3,212.4$ & 538.6 & 271.9 & 17.6 & $10,462.5$ & 8.6 & 1.6 & This study \\
\hline $\begin{array}{l}\text { Artificial } \\
\text { saltlicks }\end{array}$ & 7.2 & 16,774 & 347.8 & 566.8 & $1,054.7$ & $2,879.5$ & $1,500.5$ & 271.9 & 17.8 & $6,796.9$ & 9.4 & 1.8 & This study \\
\hline $\begin{array}{l}\text { Natural } \\
\text { saltlicks }\end{array}$ & 7.3 & $9,583.8$ & 378.2 & 954.3 & $3,021.7$ & 7,377.5 & 1,577 & 237.9 & 27.1 & $14,761.6$ & 11.3 & 1.7 & This study \\
\hline $\begin{array}{l}\text { San Miguel } \\
\text { Reservation } \\
\text { Caqueta } \\
\text { Department, } \\
\text { Colombia }\end{array}$ & 6.5 & - & 278.5 & 42,500 & $1,005,000$ & 397,500 & 240,000 & 17.8 & 2.2 & 115.5 & 0.7 & - & $\begin{array}{l}\text { Molina et } \\
\text { al. (2014) }\end{array}$ \\
\hline $\begin{array}{l}\text { Tambopata } \\
\text { Research } \\
\text { Centre, Peru }\end{array}$ & 8.7 & - & - & 36,000 & 213,000 & 213,000 & 592,000 & 16.9 & 2.3 & 119 & 0.7 & - & $\begin{array}{l}\text { Brightsmith } \\
\text { et al. } \\
(2008)^{53}\end{array}$ \\
\hline $\begin{array}{l}\text { Tambopata } \\
\text { Natural } \\
\text { Reserve } \\
\text { Buffer } \\
\text { Zone, Peru }\end{array}$ & - & - & - & 27,000 & 124,000 & 459,000 & 110,000 & - & - & - & - & - & $\begin{array}{l}\text { Brightsmith } \\
\text { and } \\
\text { Aramburu } \\
(2004)^{54}\end{array}$ \\
\hline $\begin{array}{l}\text { Wild forage, } \\
\text { Beijing, } \\
\text { China }\end{array}$ & - & - & 2,494 & $15,915.5$ & $29,989.5$ & 3,650 & 145 & - & 60.9 & 553.4 & - & - & $\begin{array}{l}\text { Lihong et } \\
\text { al. }(2007)^{46}\end{array}$ \\
\hline $\begin{array}{l}\text { Beijing Zoo } \\
\text { forage, } \\
\text { China }\end{array}$ & - & - & $3,226.5$ & 7,118 & $11,563.5$ & $2,603.5$ & $2,181.3$ & - & 27.3 & 367.9 & - & - & $\begin{array}{l}\text { Lihong et } \\
\text { al. }(2007)^{46}\end{array}$ \\
\hline $\begin{array}{l}\text { Asian } \\
\text { Elephant } \\
\text { Blood }\end{array}$ & - & - & - & - & - & - & - & $\mathrm{N} / \mathrm{A}$ & 6.1 & - & 0.8 & 0.4 & $\begin{array}{l}\text { Wiedner et } \\
\text { al. }(2011)^{47}\end{array}$ \\
\hline
\end{tabular}

The most common chemical component in soils in SWS and KNP were Fe and Mg (natural saltlicks >artificial saltlicks > general soils). At our study area, the amount of Se was consistently the lowest of all nutrient types in both areas with natural saltlicks, followed by artificial saltlicks and then general soils having the lowest concentrations respectively. Therefore, it can be seen that in both areas Fe and Mg were highest and Se was lowest. This finding was similar with Huai Kha Khaeng Wildlife Sanctuary ${ }^{45}$. Minerals were found in natural saltlicks at higher levels than general soil as was found in natural saltlicks of Huai Kha Khaeng Wildlife Sanctuary. These minerals were higher than baseline levels of trace metals in the food ( $\mathrm{Mg}, \mathrm{Na}, \mathrm{Zn}$ and Fe) in zoo ${ }^{46}$ and blood (Fe, Zn, Na, Mg and Ca) of captive Asian elephants ${ }^{47}$ (Table 3).

Higher concentrations of $\mathrm{Mg}, \mathrm{Ca}, \mathrm{Mn}, \mathrm{Fe}, \mathrm{Zn}$ and $\mathrm{Cu}$ in natural saltlicks than in general soil can thus represent an important nutrient supplement to wild elephant enabling their forage to sustain their body and health ${ }^{45}$, especially Ca required to support their bones and ivory ${ }^{48}$. Seidensticker and McNeely ${ }^{45}$ also describe $\mathrm{Na}$ and an important driver of geophagy.

In general soils, SWS and KNP differed in their amounts of minerals with soil in SWS having higher mineral contents than in KNP due to SWS having been designated as a protected area by the Royal Forest Department pursuant to Wildlife Reservation and Protection Act 2019 and not having been subjected to resource degradation over time such as in KNP ${ }^{49}$. The degradation of KNP was mostly caused by other land use demands as humans were unrestricted in converting forest to cropland and hunted wild animals for food. The Conservation and Restoration of Kui Buri National Forest Project 
under His Majesty the King's Royal Initiation began in $1997^{34}$. However, levels of K, Na and Se were similar in both study sites. While KNP had salinity in general soils at higher levels than in SWS. This result agreed with the study on the development scheme of lands with agricultural difficulties in the western area of Thailand, which reported that the soil series under soil salinity problems were the Tha Chin Series, which were founded in Prachuap Khiri Khun and the Nong Kae Series ${ }^{50}$.

In natural saltlicks, $\mathrm{P}, \mathrm{K}, \mathrm{Ca}, \mathrm{Mg}$, Ze and $\mathrm{Cu}$ are rich at both study areas, while Ca and Mg were lower in SWS than KNP. Na, Fe and Se were not significantly different in both areas. Hence, SWS is not faced with minerals deficiency in natural saltlicks, but KNP may need to supplement some minerals to enrich the minerals in the artificial saltlicks depending on the spatial condition and composition of soil in each area. This difference in mineral concentration may lead to differing mineral concentration in the forage of elephants ${ }^{51}$.

Artificial saltlicks were found to be important to enrich the minerals in general soils and elephants, but, P, K, Mg, Mn, Ze, Fe and Cu in SWS and KNP were different, because of differences in historical land-use practices over time, and differences in the provision of artificial saltlicks in each area ${ }^{51}$. Currently, providing artificial saltlicks is not specifically formulated and hence, each area should add minerals associated with the specific soil condition of the local area rather than merely providing artificial saltlicks with salt that attracted few wild animals for utilization ${ }^{52}$.

Mineral compositions in general soils and natural saltlicks in both areas were different. For preparation of future artificial saltlicks, the mineral composition of the local area needs to be understood as a guideline for making cost-effective and suitable artificial saltlicks for elephants and other geophagies.

This study suggests that the concentration of macronutrients in descending order for natural saltlicks in $\mathrm{SWS}$ was $\mathrm{Ca}>\mathrm{Mg}>\mathrm{Na}>\mathrm{K}>\mathrm{P}$, while macronutrients in artificial saltlicks were arranged in the following descending order as $\mathrm{Mg}>\mathrm{Na}>\mathrm{K}>\mathrm{Ca}>\mathrm{P}$. For KNP, the natural saltlicks had a descending concentration order of $\mathrm{Mg}>\mathrm{Ca}>\mathrm{Na}>\mathrm{K}>\mathrm{P}$, while for artificial saltlicks it was found to be $\mathrm{Mg}>\mathrm{Na}>\mathrm{Ca}>\mathrm{K}>\mathrm{P}$. The salinity was found significantly higher in the artificial when compared to the natural saltlicks, while $\mathrm{P}, \mathrm{Ca}, \mathrm{Na}, \mathrm{Mn}$ and $\mathrm{Zn}$ were not different. Overall SWS contained higher levels of nutrients when compared to KNP. According to the high number of artificial saltlicks in KNP, salinity in KNP was much higher than in SWS as these artificial saltlicks add salt to the system. Other minerals such as P, K, Mg, Mn, Ze, Fe and Cu in both areas are not significantly different. Ca, Na and Se were higher in SWS than in KNP. Finally, managers should provide artificial saltlicks that are specifically formulated by adding minerals based on the local spatial distribution of nutrients found in the general soil types of a specific area to make them suitable for wild elephant and other geophagies. We recommend further studies on the relationships between wild elephant distribution and spatial distribution and the occurrences of natural saltlicks in the area. Forage samples should be investigated for their composition of minerals to ensure the quantities are suitably available for elephants. Artificial saltlicks are important where low concentrations of mineral elements are found in forage or natural saltlicks.

\section{Declarations}

\section{Acknowledgements}

We thank to the Salakphra Wildlife Sanctuary and Kui Buri National Park, Department of National Parks, Wildlife and Plants for providing permission and assistance for data collection. Our appreciation and thanks to Thomas Neal Stewart, Mahidol University, Thailand, for editing the manuscript. This project was funded by Mahidol University.

\section{Contributions}

R. Chaiyarat and S. Kanthachompoo conceived the research and designed the experiments. R. Chaiyarat, N. Thongthip and M. Yuttitham performed the experiments. R. Chaiyarat and S. Kanthachompoo analyzed the data, wrote the article and edited the manuscript. All authors read and approved the final manuscript and agree to authorship and submission of the manuscript for peer review.

\section{Ethics declarations}

\section{Competing interests}

The authors declare no competing interests.

\section{Additional information}

Publisher's note Springer Nature remains neutral with regard to jurisdictional claims in published maps and institutional affiliations(Pty)

\section{Rights and permissions}

Open Access This article is licensed under a Creative Commons Attribution 4.0 International Li-cense, which permits use, sharing, adaptation, distribution and reproduction in any medium or format, as long as you give appropriate credit to the original author(s) and the source, provide a link to the Creative Commons license, and indicate if changes were made. The images or other third party material in this article are included in the article's Creative Commons license, unless indicated otherwise in a credit line to the material. If material is not included in the article's Creative Commons license and your intended use is not permitted by statutory regulation or exceeds the permitted use, you will need to obtain permission directly from the copyright holder. To view a copy of this license, visit http://creativecommons.org/licenses/by/4.0/. 


\section{References}

1. Choudhury, A. L., Choudhury, D. K., Desai, A., Duckworth, J. W., Easa, P. S., Johnsingh, A. J. T., Fernando, P., Hedges, S., Gunawardena, M., Kurt, F., Karanth, U., Lister, A., Menon, V., Riddle, H., Rübel, A. \& Wikramanayake, E. (IUCN SSC Asian Elephant Specialist Group). Elephas maximus. The IUCN Red List of Threatened Species 2008, e.T7140A12828813 (2018).

2. Sukumar, R. The Living Elephants: Evolutionary Ecology, Behavior, and Conservation. (Oxford University Press 2003).

3. Perera, O. B. (2009). The human-elephant conflict: A review of current status and mitigation methods. Gajaha 30, 41-52 (2009).

4. Wildlife Conservation Office. Master Plan for the National Elephant Conservation. (Department of National Park Wildlife and Plant Conservation, Ministry of Natural Resources and Environment 2003, In Thai).

5. Chaiyarat, R., Youngpoy, N., \& Prempree, P. Wild Asian elephant Elephas maximus population in Salakphra Wildlife Sanctuary, Thailand. Endanger. Species Res. 29, 95-102 (2016).

6. Srikrachang, M., \& Srikosamatara, S. Elephant crop raiding problems and their solutions at Kui Buri National Park, southwestern Thailand. Nat. His. Bull. Siam Soc. 53, 87-109 (2005).

7. Srikrachang, M., Kiatprajak, S., Bidayabha, T., Tanasarnpaiboon, S., Sang-indra, C., Saenthawee, D., Wongsuwan, S. Wild elephant counting weeks in the King's Project area, Kui Buri National Park, Southwestern Thailand. Gajah 31, 32-35 (2009).

8. Sukumar, R. Ecology of the Asian elephant in southern India. I. Movement and habitat utilization patterns. J. Trop. Ecol. 5(1), 1-18 (1989).

9. Sianga, K., \& Fynn, R. The vegetation and wildlife habitats of the Savuti-Mababe-Linyanti ecosystem, northern Botswana. Koedoe https://doi.org/10.4102/koedoe.v59i2.1406 (2017).

10. Ayotte, J. B., Parker, K. L., Arocena, J. M., \& Gillingham, M. P. Chemical composition of lick soils: Functions of soil ingestion by four ungulate species. J. Mammal. 87(5), 878-888 (2006).

11. Chew, M. Y., Hymeir, K., Nosrat, R., \& Shahfiz, M. A. Relation between grasses and large herbivores at the Ulu Muda salt licks, Peninsular Malaysia. J. Trop. For. Sci. 26(4), 554-559 (2014).

12. Morales, M. A. The importance of general soil licks to wildlife and humans in subtropical Paraguay, South America. (University of Wisconsin 2009).

13. Sienne, J. M., Buchwald, R., \& Wittemyer, G. Differentiation in mineral constituents in elephant selected versus unselected water and soil resources at Central African bias (forest clearings). Eur. J. Wildl. Res. 60, 377-382 (2014).

14. Srisakdi, T. The mineral supplement to cattles releasing to in grass field. (M.Sc. Thesis, Kasetsart University 1982, In Thai).)

15. Kalumanga, E., Mpanduji, D. G., \& Cousins, S. A. O. (2016). Geophagic termite mounds as one of the resources for African elephants in Ugalla Game Reserve, Western Tanzania. Afr. J. Ecol. 55, 91-100 (2016).

16. Dethier, V. G. The taste of salt. Am. J. Sci. 65(6), 744-751 (1977).

17. Kreulen, D. A., \& Jager, T. The significance of soil ingestion in the utilization of arid rangelands by large herbivores, with special reference to natural licks on the Kalahari pans. In: Gilchrist F. M. C., \& Mackie R. I. (Eds.). Herbivore nutrition in the subtropics and tropics. (Science Press 1984).

18. Buddhachat, K., Klinhom, S., Siengdee, P., Brown, J.L., Nomsiri, R., Kaewmong, P., Thitaram, C., Mahakkanukrauh, P., \& Nganvongpanit, K. Elemental analysis of bone, teeth, horn and antler in different animal species using non-invasive handheld x-ray fluorescence. PLOS ONE https://doi:10.1371/journal.pone.0155458 (2016).

19. Katole, S. B., Das, A., Saini, M., \& Sharma, A. K. Effect of moderate work on intake and serum profile of minerals in semi-captive Asian elephants (Elephas maximus) fed sugarcane based diet. Indian J. Anim. Sci. 85(10), 1126-1129 (2015).

20. Nganvongpanit, K., Brown, J. L., Buddhachat, K., Somgird, C., \& Thitaram, C. Elemental analysis of Asian elephant (Elephas maximus) teeth using xray fluorescence and a comparison to other species. Biol. Trace Element Res. 170, 94-105 (2016).

21. Nganvongpanit, K., Siengdee, P., Buddhachat, K., Brown, J. L., Klinhom, S., Pitakarnnop, T., Angkawanish, T., \& Thitaram, C. Anatomy, histology and elemental profile of long bones and ribs of the Asian elephant (Elephas maximus). Anat. Sci. Int. 92(4), 554-568 (2017).

22. Barnes, P. Forage yield and soil improvement potential of some annual and short-term perennial legumes at two sites in Ghana. Ghana J. Agri. Sci. 32, 47-51 (1999).

23. Nelson, A., Bidwell, P., \& Sillero-Zubiri, C. A review of humane elephant conflict management strategies. People and Wildlife Initiative. (Wildlife Conservation Research Unit, Oxford University 2003).

24. Senthilkumar, K., Mathialagan, P., Manivannan, C., Gomathinayagam, S., \& Jayathangaraj, M. G. Human-elephant conflict: Case study from Tamil Nadu. Int. J. Environ. Sci. Technol. 5(2), 445-448 (2016).

25. van de Water, A., \& Matteson, K. Human-elephant conflict in western Thailand: Socio-economic drivers and potential mitigation strategies. PLoS ONE https://doi.org/10.1371/journal.pone.0194736 (2018).

26. Sukumar, R. Ecology of the Asian elephant in southern India, Il: Feeding habits and crop raiding patterns. J. Trop. Ecol. 6(1), 33-53 (1990).

27. Smith, R. J., \& Kasiki, S. M. A Spatial Analysis of Human-Elephant Conflict in the Tsavo Ecosystem, Kenya (A Report to the African Elephant Specialist Group, Human-Elephant Conflict Task Force, of IUCN 1999).

28. Naughton-Treves, L. Predicting patterns of crop damage by wildlife around Kibale National Park, Uganda. Conserv. Biol. 12(1), 156-168 (1998).

29. World Wide Fund for Nature Thailand Office. Action Plan for the Conservation of Asian Elephants in Thailand 1999-2001. (Siam Thongkit Co. Ltd. 2000, In Thai). 
30. Budka, B. Economic valuation for wild elephant management in Thailand. (Ph.D. Thesis, Kasetsart University 2007).

31. Mosquera, D., Vinueza-Hidalgo, G., \& Blake, J. G. Patterns of mineral lick visitation by Linnaeus's two-toed sloth Choloepus didactylus (Pilosa. Megalonychidae) in eastern Ecuador. Notes S. Am. Mamm. https://doi:10.31687/saremNMS.19.0.07 (2019).

32. Simpson, B. K., Nasaruddin, N., Traeholt, C., \& Nor, S. Md. Mammal Diversity at Artificial Saltlicks in Malaysia: A Targeted Use. Front. Environ. Sci. 16, https://doi.org/10.3389/fenvs.2020.556877 (2020).

33. Salakphra Wildlife Sanctuary. Master plan of Salakphra Wildlife Sanctuary, Kanchanaburi Province B.E. 2554-2558. (Department of National Park, Wildlife and Plant Conservation, Protected Areas Regional Office 3 (Ban Pong) 2011, In Thai).

34. Kui Buri National Park. Summary Results for the year 2003. (Kui Buri National Park, Prachuap Khiri Khan 2003, In Thai).

35. Mahaney, W. C., \& Krishnamani, R. Understanding geophagy in animals: Standard procedures for sampling soils. J. Chem. Ecol. 29(7), 1503-1523 (2003).

36. IGAC-Instituto Geográfico Agustin Codazzi. Métodos analíticos del laboratorio de suelos. (Bogotá: Imprenta Nacional de Colombia 2006).

37. Bouyoucos, G. J. Directions for making mechanical analysis of soils by the hydrometer method. Soil Sci. 4, 225-228 (1936).

38. Vocasek, F. F., \& Friedericks, J. B. Soil micronutrient extraction by Mehlich-3 compared to CaCl2-DTPA. Commun. Soil Sci. Plant Anal. 25(9-10), 15831593 (1994).

39. McLeod, S. Studies on wet oxidation procedures for the determination of organic carbon in soils. (CSIRO Division of Soils, Notes on Soil Techniques 1973).

40. Nigel, T. Methods in Agricultural Chemical Analysis: A Practical Handbook. (Biddles Ltd 2002).

41. McCune, B., \& Mefford, M. J. PC-ORD: Multivariate Analysis of Ecological Data, Version 5.0 for Windows. (MjM Software 2006).

42. Sukmasuang, R. Population density of Asian elephants in Huai Kha Khaeng Wildelife Sanctuary. Thai J. For. 28(1), 40-50 (2009) (In Thai).

43. Submee, A. The use of advantages from natural salt licks and artificial salt licks by wildlife at Phu Kiew Wildlife Sanctuary, Chaiyaphum province. (M.Sc. Thesis. Bangkok, Kasetsart University 1986, InThai).

44. Sitienei, A. J., Ge, J. W., Ngene, S. M., De La Paix, M. J., \& Waweru, F. K. Analysis in the concentration, determination and comparison of some mineral elements in the natural salt-licks utilized by elephants: Mt. Elgon National Park case study. Adv. Mat. Res. 356-360, 1796-1800 (2012).

45. Seidensticker, J. \& McNeely, J. Observations on the use of natural licks by ungulates in the Huai Kha Khaeng Wildlife Sanctuary, Thailand. Nat. His. Bull. Siam Soc. 26, 25-34 (1975).

46. Lihong, W., Liu, L., Qian, H., Jinguo, Z., \& Li, Z. Analysis of nutrient components of food for Asian elephants in the wild and in captivity. Front. Biol. China 2(3), 351-355 (2007).

47. Wiedner, E. B., Takeuchi, N. Y., Isaza, R., \& Barber, D. Baseline levels of trace metals in blood of captive Asian elephants (Elephas maximus). J. Zoo Wildl. Med. 42(2), 360-362 (2011).

48. Barboza, G. E., Cantero, J. J., Núñez, C., Pacciaroni, A., \& Espinar, L. A. Medicinal plants: A general review and a phytochemical and ethnopharmacological screening of the native Argentine Flora. Kurtziana 34(1-2), 7-365 (2009).

49. Royal Thai Government Gazette. Wildlife Preservation and Protection Act, B.E.2562 (2019) of Thailand. http:www.ratchakitcha.soc.go.th/ (2019) (In Thai).

50. Sutthawas, K. Guidelines for Developing Problem Soils for Agriculture in the Western Area of Thailand. (Land Development Office District 10, land development Department 2014, In Thai).

51. Kanchanasakha, B., Tanhikorn, S., Vinitpornsawan, S., Prayoon, U., \& Phangbuppha, K. State of Large Mammals in Thailand. (Wildlife Research Division, Department of Wildlife Conservation National Park, Wildlife and Plant Conservation 2010).

52. Bhumpakphan, N. Ecological characteristics and habitat utilization of gaur (Bos gaurus H. Smith, 1827) in different climate sites. (Ph.D. Thesis, Kasetsart University 1997).

53. Brightsmith, D. J., Taylor, J., \& Phillips, T. D. The roles of soil characteristics and toxin adsorption in avian geophagy. Biotropica 40, 766-774 (2008). 54. Brightsmith, D., \& Aramburu, R. Avian geophagy and soil characteristics in southeastern Peru. Biotropica 36(4), 534-543 (2004).

\section{Figures}




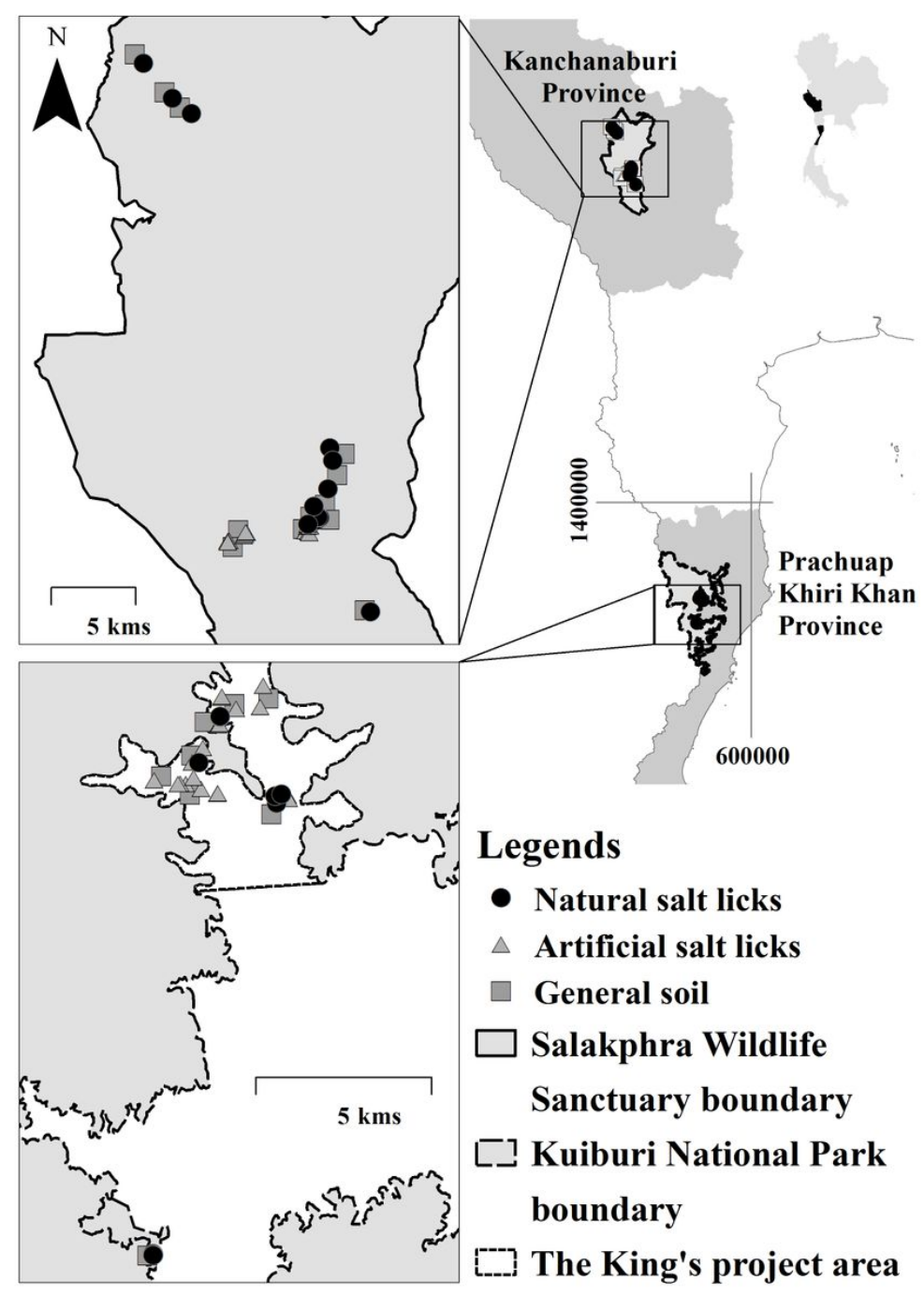

Figure 1

Salakphra Wildlife Sanctuary in Kanchanaburi province and Kui Buri National Park in Prachuap Khiri Khan Province Note: The designations employed and the presentation of the material on this map do not imply the expression of any opinion whatsoever on the part of Research Square concerning the legal status of any country, territory, city or area or of its authorities, or concerning the delimitation of its frontiers or boundaries. This map has been provided by the authors. 

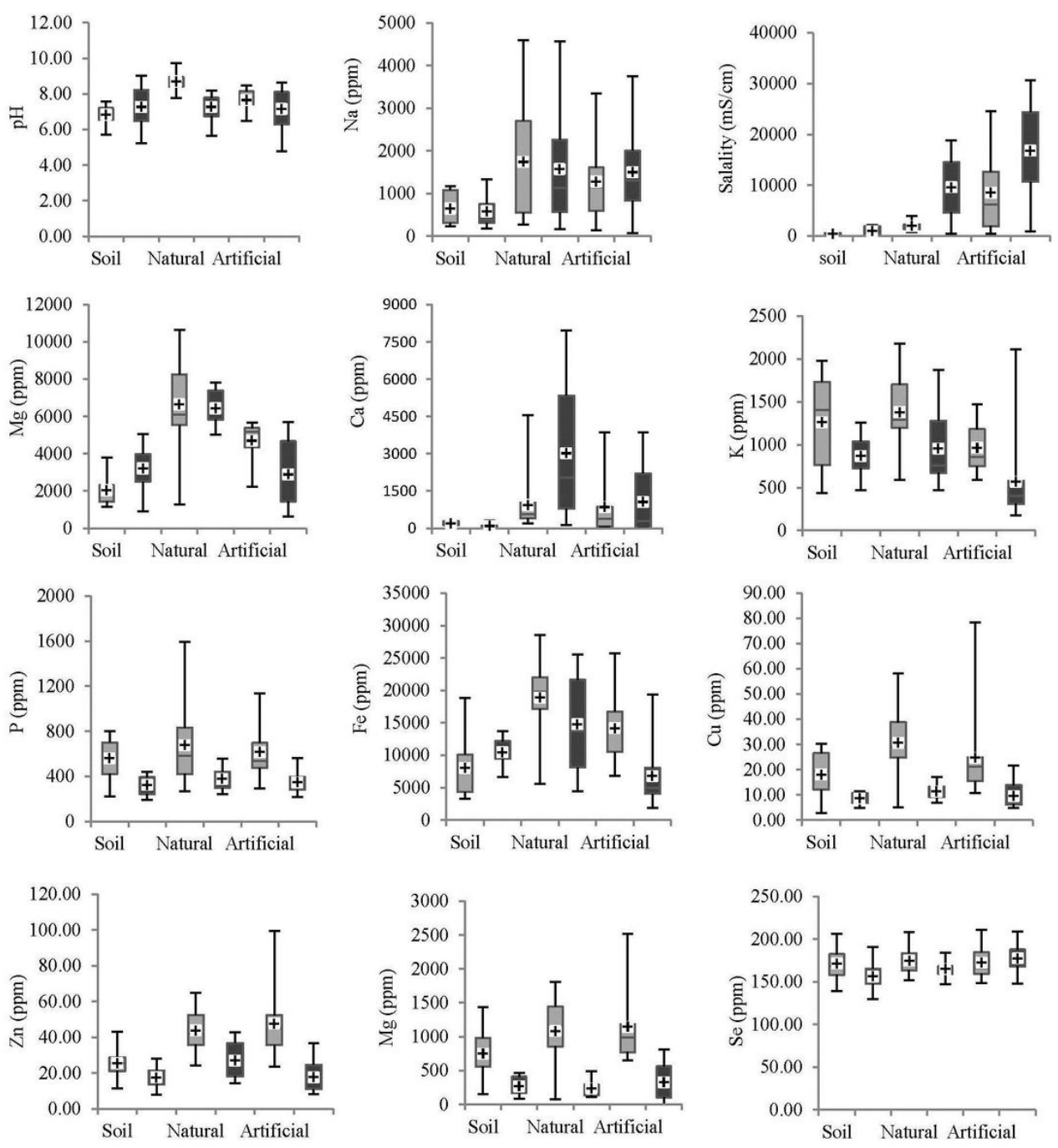

\section{Figure 2}

Soil reaction, salinity and chemical composition of general soils (Soil), natural saltlicks (Natural) and artificial saltlicks (Artificial) from Salakphra Wildlife Sanctuary (gray) and Kui Buri National Park (black) 


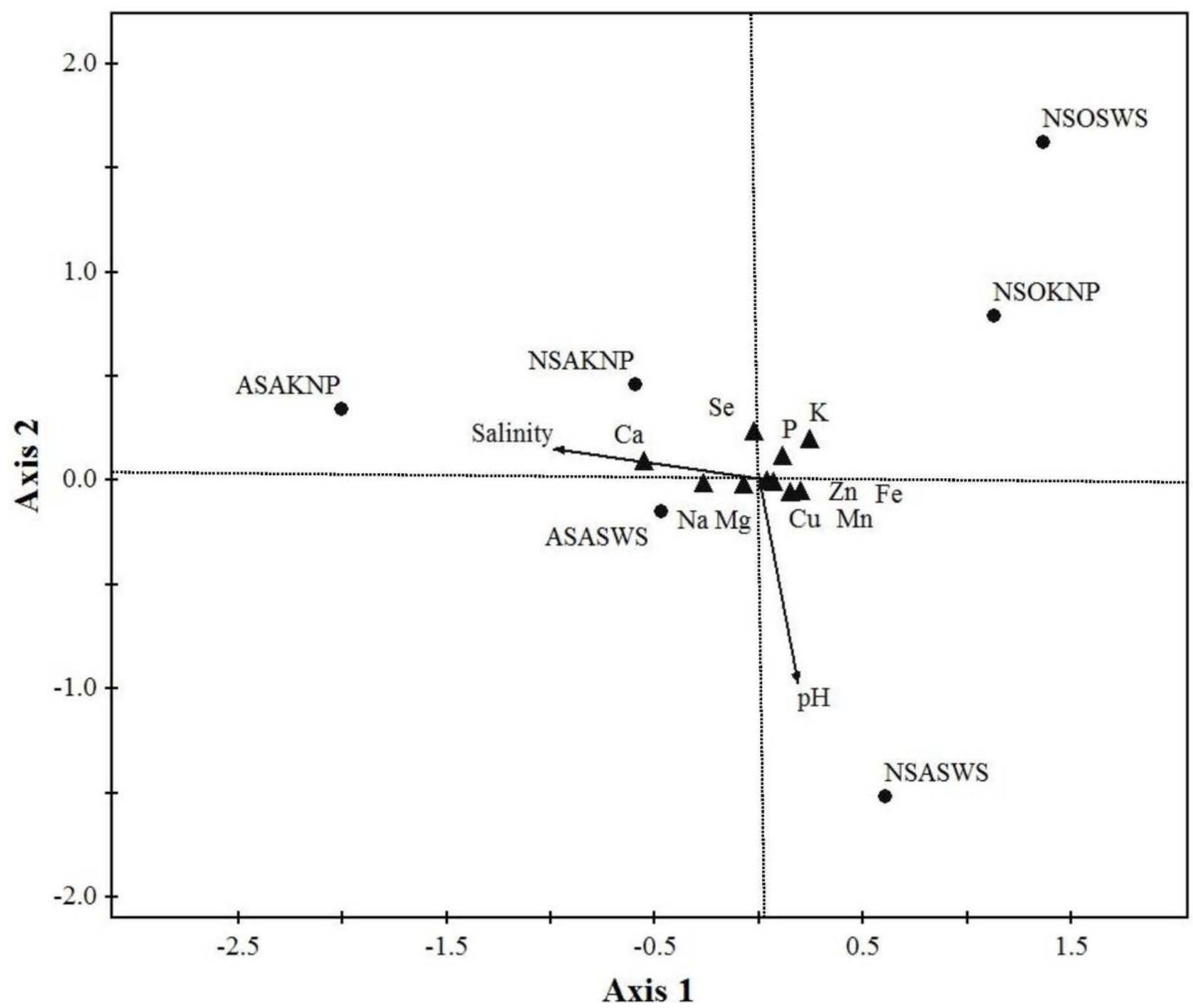

Figure 3

Relationships of 10 minerals and environmental parameters ( $\mathrm{pH}$ and salinity) among general soil, natural saltlicks and artificial saltlicks in Salakphra Wildlife Sanctuary and Kui Buri National Park (NSOSWS = general soil in Salakphra Wildlife Sanctuary, ASASWS = artificial saltlicks in Salakphra Wildlife Sanctuary, NSASWS = natural saltlicks in Salakphra Wildlife Sanctuary, NSOKNP = general soil in Kui Buri National Park, ASAKNP = artificial saltlicks in Kui Buri National Park and NSAKNP = natural saltlicks in Kui Buri National Park). 